\title{
Youth Development and Public Library Significance
}

\author{
Dasimah Omar' ${ }^{1}$, Saberi Othman², \\ Kamarul Ariff Omar'1, Mona Fatini Ibrahim¹ \\ ${ }^{1}$ Faculty of Architecture, Planning and Surveying, \\ Universiti Teknologi Mara (UiTM), 40450 Shah Alam, Selangor, Malaysia \\ 2 Faculty of Science and Mathematics, \\ Universiti Pendidikan Sultan Idris (UPSI), 35900 Tanjong Malim, Perak Malaysia \\ dasimaho@yahoo.com
}

\begin{abstract}
The purpose of this paper is to examine the usage of public library towards youth development. A public library offers information and educational resources to a community. Being that in the modern world, there are other modes in seeking information, the public library is often disregarded and being ignored of its existence. Factors that affect the use of public libraries such as accessibility, availability, comfortability and the maintenance of it plays an important role in determining its usage among youth. The paper will look into four research areas of the urban and rural areas in Malaysia as the base of this study to see whether the public library is used by the youth to gain information apart from other resources available.
\end{abstract}

Keywords: Public Library, Youth, Youth development

eISSN 2398-4279 @ 2018. The Authors. Published for AMER ABRA cE-Bs by e-International Publishing House, Ltd., UK. This is an open access article under the CC BY-NC-ND license (http://creativecommons.org/licenses/bync-nd/4.0/). Peer-review under responsibility of AMER (Association of Malaysian Environment-Behaviour Researchers), ABRA (Association of Behavioural Researchers on Asians) and cE-Bs (Centre for EnvironmentBehaviour Studies), Faculty of Architecture, Planning \& Surveying, Universiti Teknologi MARA, Malaysia.

https://doi.org/10.21834/ajqol.v3i14.182 


\subsection{Introduction}

A Public library is a place where people can get hold on knowledge, information or educational resources. As mentioned by Suhaila Sufar et al (2012), according to UNESCO (United Nations Educational, Scientific and Cultural Organization), a public library is defined as the local centre of information, making all kinds of knowledge and information readily available to its users. The services of the public library are provided by equality of access for all, regardless of age, race, sex, religion, nationality, language or social status.

Moreover, Suhaila Sufar (2012) also mentioned a public library as an organisation established, supported and funded by the community, either through local, regional or national government or some other form of community organisation. It provides access to knowledge, information and works of the imagination through a range of resources and services and is equally available to all members of the community regardless of race, nationality, age, gender, religion, language, disability, economic and employment status and educational attainment (IFLA - Institute Federal Library Association, undated).

Therefore a public library as a learning facility plays a strategic role in youth development. 'Youth' as defined by UNESCO are those persons between the ages of 15 and 24 years, without prejudice to other definitions by the Member States. However, "Youth" is best understood as a period of transition from the dependence of childhood to adulthood's independence and awareness of their interdependence as members of a community. Hence "youth" is often indicated as a person between the age where he/she may leave compulsory education, and the age at which he/she finds his/her first employment (UNESCO, 2016).

In the Malaysian context, referring to Raja Suzana Raja Kasim et al. (2014), there are 13.3 million youth population ages between 15 - 40 represented $46 \%$ of the total Malaysian population. The youth populations have a great impact on the development of the country. They are the major contributor in shaping the future and community wellbeing. Therefore, a positive youth development ensures youth contributes to the development and improvement of the community. Hence, the public library a place which acts as an education centre helps the youth to become more productive and increases the overall quality of life for youth in Malaysia. For that reason, this study will examine the factors that affect the use of public library amongst the youth.

\subsection{Research Background}

This research is a part of a larger project (Social Environment and Infrastructure Sustainability towards Healthy and Quality Lifestyle) which focuses mainly on the use of public library among youth. The main objective of this paper is to examine the importance of public library towards youth development in Malaysia.

There are four (4) sites which are Kuala Lumpur, Pahang, Sarawak and Sabah that were chosen for the research which both cover the west and east side of Malaysia. The sites cover both on the urban and rural areas to ensure data gathered is balanced and no bias results regarding the importance of the public library to the youth development. A total of 800 respondents participated in the data collection. The breakdown is presented in Table 1. 
Table 1: Number of respondents

\begin{tabular}{l|l|l|l}
\hline \multirow{2}{*}{ Location } & No of Respondents & \multirow{2}{*}{ Total } \\
\cline { 2 - 4 } & Urban area & Rural area & \\
\hline Kuala Lumpur (Lembah Pantai) & 400 & 0 & 400 \\
\hline $\begin{array}{l}\text { Pahang } \\
\text { (Felda Jengka) }\end{array}$ & 0 & 130 & 130 \\
\hline $\begin{array}{l}\text { Sarawak } \\
\text { (Kota Samarahan) }\end{array}$ & 0 & 130 & 130 \\
\hline $\begin{array}{l}\text { Sabah } \\
\text { (Kota Kinabalu) }\end{array}$ & 140 & 0 & 140 \\
\hline Total & 540 & 260 & 800 \\
\hline
\end{tabular}

The respondents are focused mainly on the youth with ages between 15 to 25 years old and represent both female and male gender. They were also selected based on the main three (3) races in Malaysia which represent Malay, Chinese and Indian community. In gathering data for the research, a survey was conducted using 'snowball' sampling technique. This technique is used because the participants who are mainly youth were difficult to participate in the survey. They were either too shy or anxious when asked with the questions of the questionnaire. Therefore, this 'snowball' technique helps in increasing the number of participants and finding other participants through initial contact and connection made by the earlier participants.

The survey questionnaire was developed from the earlier four (4) focus group discussion (FGD) sessions of the main research which is the Social Environment and Infrastructure Sustainability towards Healthy and Quality Lifestyle. Issues and variables regarding the research highlighted during the FGD sessions helped in developing the questionnaire. This questionnaire was divided into two (2) parts mainly Part A for respondents' background and Part $B$ for measuring the youth satisfaction level of the facilities provided in the housing community. The questionnaire was administered by the research team members for quality measures.

The questionnaire was structured to examine the utilisation of public library regarding its availability, comfortability, accessibility and maintenance. Questions were asked to determine whether the public library has brought positive impact to the youth development. During the survey, the participants were encouraged to answer all questions on the survey but were also reminded that their participation was voluntary. They were not required to answer any question that made them feel uncomfortable.

Based on the questionnaire, quantitative data is collected and analysed using Statistical Package for the Social Sciences (SPSS). Descriptive analysis is applied to examine the usage of public library among youth. Results from the analysis were to support and provide more insight regarding the usage of the public library.

\subsection{Result and Findings}

The research attempts to determine the importance of public library by measuring its usage amongst the youth by using quantitative assessment methods. The objective is to find the 
relationship between the importances of the public library towards youth development.

Table 2: Level of Respondents' Satisfaction

\begin{tabular}{l|l|l|l|l|l}
\hline \multirow{2}{*}{$\mathrm{N}$} & \multicolumn{5}{|l}{ Variables } \\
\cline { 2 - 6 } & Availability & Comfortability & Distance & Accessibility & Maintenance \\
\hline Mean & 3.65 & 3.75 & 3.69 & 3.75 & 3.74 \\
\hline Std. Deviation & 1.016 & .971 & 1.058 & 1.044 & .997 \\
\hline Variance & .971 & .943 & 1.120 & 1.091 & .994 \\
\hline
\end{tabular}

According to the table, the level of satisfaction of the public library provided in the area was indicated scale between 3 to 4 which shows the level of respondents (youth) satisfaction using the public library is between moderate to satisfied with its current conditions in terms of its availability in the area, its accessible and distance to reach the facilities, as well as the comfort and maintenance provided by the public library when used.

The value of 'availability' and 'distance' of the public library shows 3.65 , and 3.69 meaning the respondents (youth) felt moderate in using the public library as the location of the public library is either far from their home or not easily reachable in the distance. Furthermore, the value of 'comfort ability', 'accessibility' and 'maintenance' shows $3.75,3.75$ and 3.74 . The results indicate that the value of satisfaction when using the public library is reaching a satisfied level. It shows that the public library provided in the area is well maintained and give comfort ability to the respondents (youth) when using it. However, the overall result shows that the usage of public library among youth did not achieve the highest value of satisfaction.

Table 3: Availability of the Public Library in the Study Area

\begin{tabular}{l|l|l}
\hline Availability of the Public Library & No. of respondents & Percentage \\
\hline Yes & 561 & 70.1 \\
\hline No & 239 & 29.9 \\
\hline Total & 800 & 100.0 \\
\hline
\end{tabular}

Table 3 shows the availability of the public library in the surveyed sites. The results shows that $70.1 \%$ of the respondents (youth) responded 'yes' while the remaining $29.9 \%$ of the respondents (youth) responded 'no' when asked regarding the availability of the public library in their area. It shows that public libraries are provided in their area as a facility in a town or city for the public use. Referring to a study by Atsushi lkeuchi et al. (2013), libraries and other information centres must justify their existence, so the benefits of their services, even if they seem rather nebulous, cannot be ignored in evaluative studies. The study shows that public library has a significant importance to a community development. The public library is seen here as a centre of education for empowerment of community development.

Table 4: Respondents Usage of the Public Library

\begin{tabular}{l|l|l}
\hline Usage of the Public Library & No. of respondents & Percentage \\
\hline Yes & 392 & 49.0 \\
\hline No & 406 & 50.8 \\
\hline Total & 798 & 99.8 \\
\hline Missing data & 2 & 0.3 \\
\hline
\end{tabular}




\begin{tabular}{|c|c|c|}
\hline Total & 800 & 100.0 \\
\hline \multicolumn{3}{|c|}{$\begin{array}{l}\text { Even though the public library is available in the area, results of analysis shows more } \\
\text { than half }(50.9 \%) \text { of the total respondents being surveyed did not use the public library. It } \\
\text { means that the public library is not being fully utilized by the youth. It is due probably to the } \\
\text { easy access of the internet use at home or someplace else. With modern technology, youth } \\
\text { can gain information without going to the public library. } \\
\text { A study by Yueh Min Huang et al. (2015) shows that e-resources and digital libraries are } \\
\text { becoming increasingly important channels for obtaining information. A large number of } \\
\text { libraries have consequently introduced mobile communication technologies into their library } \\
\text { services, enabling users to search for information from anywhere and at any time. }\end{array}$} \\
\hline \multicolumn{3}{|c|}{ Table 5: The Distance to the Public Library } \\
\hline The distance to the Public Library & \begin{tabular}{l|l} 
No. of respondents \\
\end{tabular} & Percentage \\
\hline Very Unsatisfied & 30 & 3.8 \\
\hline Unsatisfied & 48 & 6.0 \\
\hline Moderate & 125 & 15.6 \\
\hline Satisfied & 259 & 32.4 \\
\hline Very Satisfied & 130 & 16.2 \\
\hline Total & 592 & 74.0 \\
\hline Missing data & 208 & 26.0 \\
\hline & & \\
\hline
\end{tabular}

When respondents were asked regarding the distance of the public library available in their area, results shows that $43.8 \%$ and $22.0 \%$ of the respondents feel satisfied and very satisfied with its distance. It means that more than half $(65.6 \%)$ of the respondents are pleased that the public library are reachable within walking proximity and located near their house. While $21.1 \%$ responded as moderate for the distance to reach the public library and another $8.1 \%$ and $5.1 \%$ responded unsatisfied and very unsatisfied probably due to their houses in the rural area and far from the facilities in the town centres.

Table 6: Accessibility to the Public Library

\begin{tabular}{l|l|l}
\hline Accessibility to the Public Library & No. of respondents & Percentage \\
\hline Very Unsatisfied & 35 & 4.4 \\
\hline Unsatisfied & 27 & 3.4 \\
\hline Moderate & 123 & 15.4 \\
\hline Satisfied & 272 & 34.0 \\
\hline Very Satisfied & 135 & 16.9 \\
\hline Total & 592 & 74.0 \\
\hline Missing & 208 & 26.0 \\
\hline Total & 800 & 100.0 \\
\hline
\end{tabular}

Referring to the accessibility to the Public Library, result shows that more than half $(68.7 \%)$ of the respondents were satisfied and very satisfied proving that the distance to the public library in the area are easily reachable and accessible whether by walking or using transport mode such as busses or bicycle by the respondent (youth). However, $10.5 \%$ of the 
respondents feel unsatisfied and very unsatisfied regarding the accessibility to the public library probably due to them living in the rural area and far from the town facilities such as the public library.

Table 7: Facilities provided in the Public Library

\begin{tabular}{l|l|l}
\hline Facilities provided in the Public Library & No. of respondents & Percentage \\
\hline Very Unsatisfied & 27 & 3.4 \\
\hline Unsatisfied & 25 & 3.1 \\
\hline Moderate & 136 & 17.0 \\
\hline Satisfied & 288 & 36.0 \\
\hline Very Satisfied & 117 & 14.6 \\
\hline Total & 593 & 74.1 \\
\hline Missing data & 207 & 25.9 \\
\hline Total & 800 & 100.0 \\
\hline
\end{tabular}

Table 7 shows the respondents (youth) level of satisfaction regarding the facilities provided in the public library when used. Results show that $48.6 \%$ of the respondents (youth) were satisfied and another $19.7 \%$ were very satisfied with the facilities provided. It shows that more than half $(68.3 \%)$ of the respondents feel that the facilities such as the computers, wireless internet access, study and training room, photocopying and printing provided in the public library is sufficient for the use of the public.

According to Kurtis McDonald (2015), by providing access to public use computers and training sessions geared around specific applications, libraries are now increasingly at the forefront of technological fluency development. Kurtis (2015) also added that if libraries are going to truly meet the needs of their patrons going forward, innovative information literacy training must be re-envisioned as a service priority in all library functions.

Table 8: Maintenance of facilities in the Public Library

\begin{tabular}{l|l|l}
\hline Maintenance of facilities in the Public Library & No. of respondents & Percentage \\
\hline Very Unsatisfied & 30 & 3.8 \\
\hline Unsatisfied & 27 & 3.4 \\
\hline Moderate & 129 & 16.1 \\
\hline Satisfied & 286 & 35.8 \\
\hline Very Satisfied & 120 & 15.0 \\
\hline Total & 592 & 74.0 \\
\hline Missing data & 208 & 26.0 \\
\hline Total & 800 & 100.0 \\
\hline
\end{tabular}

When respondents were asked regarding the conditions of facilities provided in the public library when used, results show that $48.6 \%$ of the respondents (youth) were satisfied and another $19.7 \%$ were very satisfied with the facilities provided. Table 8 shows that more than half $(68.3 \%)$ of the respondents feel that the facilities provided in the public library is in good condition and properly maintained for the use of the public. While, $22.9 \%$ responded as moderate when asked regarding the facilities provided. Another $4.2 \%$ and $4.6 \%$ of the respondents (youth) were unsatisfied and very unsatisfied regarding the facilities provided. It is probably due to the time when they were using the facilities provided, it is in bad condition 
or not properly maintained.

\subsection{Conclusion}

Public library today needs to embrace a more engaged role to meet the requirement of the user likely for daily, academic or professional use. It is important to understand the role of public library to community development especially the youth population. The role of public library helps contribute to the growth of education amongst youth and this in turns increase and strengthens the productivity of the community as well as enhances youth development. By understanding all of the influences on the perception and expectation of the participants regarding the usage of the public library, future challenges which effects both directly and indirectly will helps in developing a positive youth development for the future.

\section{Acknowledgement}

This study is made possible by the Long term Research Grant Scheme (LRGS 2014-0006106-42), Universiti Pendidikan Sultan Idris Perak associated with Universiti Teknologi MARA Shah Alam and Universiti Putra Malaysia.

\section{References}

Atsushi Ikeuchi et al. (2013), Double-bounded Dichotomous Choice CVM for Public Library Services in Japan. Procedia - Social and Behavioral Sciences 73 (2013) 205 - 208 doi: 10.1016/j.sbspro.2013.02.042

Dasimah bt Omar, Kamarul Ariff b Omar, Saberi b Othman, Zaharah bt Mohd Yusoff (2016), Walkability for Urban Public Housing Park in Urban. Environment-behaviour Proceedings Journal Vol 1 (No 3). 311-317.

Dasimah bt Omar, Kamarul Ariff b Omar, Saberi b Othman and Zaharah bt Mohd Yusoff (2016), User Perception of Walkability design for Urban Public Housing Park. Ace-Bs Taipei.

Kamarul Ariff Omar, Dasimah bt Omar, Saberi b Othmanand Zaharah bt Mohd Yusoff (2016),Reviewing Youth Facility Requirements for Low Cost Housing in Malaysia. ElsevierProcedia - Social and Behavioral Sciences 222(2016): 702-709.

Kamarul Ariff b Omar, Dasimah bt Omar, Saberi b Othman and Zaharah bt Mohd Yusoff. (2016), Youth Satisfaction for Outdoor Activity in Urban Neighbourhood Space. AMER International Conference on Quality of Life .Grand Aston City Hall, Medan, Indonesia.

Kamarul Ariff b Omar, Dasimah bt Omar, Saberi b Othman, and Zaharah bt Mohd Yusoff. (2016), Youth Participation in Urban Neighbourhood Community. AMER International Conference on Quality of Life. Grand Aston City Hall, Medan, Indonesia

Kamarul Ariff b Omar, Ahmad Suhaimi b Ismail, Dasimah bt Omar, Saberi b Othman (2016), Well-Being Assessment of Youth in Urban Marginalized Community. Environment-behaviour Proceedings Journal Vol 1 (No 3). 60-68.

Kurtis McDonald. (2015), Re-envisioning Libraries for Training and Literacy Development. Procedia - Social and 
Behavioral Sciences 176 (2015) 504 - 508. doi:10.1016/j.sbspro.2015.01.503

Raja Suzana Raja Kasim et al. (2014), Regenerating Youth Development through Entrepreneurship. Procedia Social and Behavioral Sciences 129 (2014) 322 - 327 doi:10.1016/j.sbspro.2014.03.683

Suhaila Sufar et al. (2012), Towards a better Design: Physical Interior Environments of Public Libraries in Peninsular Malaysia. Procedia - Social and Behavioral Sciences 42 (2012) 131 - 143. doi: 10.1016/j.sbspro.2012.04.174

Yueh Min Huang et al. (2015), Development and evaluation of the mobile library service system success model. The Electronic Library Vol. 33 Iss 6, 1174 - 1192 http://dx.doi.org/10.1108/EL-06-2014-0094 